\title{
Characterization of L-Arabinose-induced Bulge Formation in Escherichia coli IFO 3545 Using L-Arabinose-negative Mutants
}

\author{
Toshio Tanaka, Hisae Muroi, Chikao Sunada, \\ Makoto TANIGUCHI and Susumu OI \\ Faculty of Science, Osaka City University, Sugimoto 3-3-138, \\ Sumiyoshi-ku, Osaka 558, Japan \\ Received January 11, 1988
}

\begin{abstract}
L-Arabinose-induced bulge formation in Escherichia coli IFO 3545 was observed in L-ribulose5-phosphate (L-Ru5P) 4-epimerase deficient mutants such as ara-207 and ara-208 as well as the wild type in hypertonic medium with $5 \%$ sodium chloride but not in the other L-arabinose-negative mutants. Unlike the case with the wild type strain, bulge formation of ara-207 and ara-208 could be induced with $1 \% \mathrm{~L}$-arabinose without sodium chloride. These results indicated that $\mathrm{L}$-arabinose must be metabolized to L-Ru5P for induction of buige cells and the presence of $5 \%$ sodium chloride was thought to regulate the activity of L-Ru5P 4-epimerase to cause accumulation of L-Ru5P as an effector molecule for bulge formation. Also, L-arabinose-induced morphological change was suggested to proceed via a mechanism similar to penicillin-induced inhibition of peptidoglycan metabolism.
\end{abstract}

The cells of $E$. coli have a variety of responses in physiological and morphological aspects according to the osmotic pressure of the environment. ${ }^{1 \sim 8)}$ Plasmolysis seems to be a fundamental response induced under hypertonic conditions with osmotically active substances such as glycerol and sucrose. ${ }^{14)}$ The cellular composition of outer membrane proteins $^{5)}$ as well as intracellular contents of putrescine $^{6)}$ and a certain carbohydrate ${ }^{7)}$ are osmotically regulated by the presence of sodium or potassium chloride in E. coli. The presence of sodium chloride is also known to affect the activity of glucose-6-phosphate dehydrogenase. ${ }^{8)}$ In a previous study, L-arabinose was found to induce a characteristic morphological change (bulge formation) in E. coli IFO 3545 under hypertonic conditions with sodium chloride. ${ }^{9)}$ This morphological change was quite similar to those induced by several $\beta$ lactams such as penicillin $G$ and ampicillin that specifically inhibit peptidoglycan transpeptidases involved in cell division, ${ }^{10,11)}$ because L-arabinose-induced bulge cell appearance was also paralleled by repression of the bacterial cell division. ${ }^{9)}$ D-Xylose did not cause bulging, ${ }^{9)}$ although D-xylulose-5-phosphate (D-Xu5P) is a common intermediate both in L-arabinose and D-xylose metabolism. It is likely that intracellular level of an enzyme specific for initial L-arabinose metabolism is related to the L-arabinose-induced morphological change. The presence of $5 \%$ sodium chloride may regulate the above enzyme level or activity. In this study, we tried to find out a relationship between the $\mathrm{L}$-arabinose-induced morphological change of $E$. coli (IFO 3545) and its L-arabinose metabolizing enzymes using several L-arabinosenegative mutants with defects in each of the L-arabinose metabolizing enzymes. Also, the nature of bulge cell formation with L-arabinose was compared with penicillin-induced growth inhibition and morphological change.

\section{MATERIALS AND METHODS}

Bacterial strain and media. Escherichia coli IFO 35459) and its mutants were used in this study. Nutrient medium ${ }^{9}$ consisted of $1.7 \mathrm{~g}$ of beef extract, $5.0 \mathrm{~g}$ of Polypepton, and $1.7 \mathrm{~g}$ of $\mathrm{K}_{2} \mathrm{HPO}_{4}$ in $1000 \mathrm{ml}$ of distilled water and was 
designated as $1 \%$ nutrient broth (NB). In the nutrient broth designated as $3 \% \mathrm{NB}$, the concentration of each component was three times as much as $1 \% \mathrm{NB}$. Unless otherwise stated, $\mathrm{pHs}$ of the above media were adjusted to 7.0. Utilization of L-arabinose was examined with eosinmethylene blue (EMB)-agar medium having the following composition: casamino acids, $8 \mathrm{~g}$; yeast extract, $980 \mathrm{mg}$; $\mathrm{K}_{2} \mathrm{HPO}_{4}, 1.96 \mathrm{~g} ; \mathrm{NaCl}, 4 \mathrm{~g}$; eosin yellow, $400 \mathrm{mg}$; methylene blue, $65 \mathrm{mg}$; $\mathrm{L}$-arabinose, $10 \mathrm{~g}$; agar, $15 \mathrm{~g}$; and distilled water, $1000 \mathrm{ml}$; $\mathrm{pH}$ 7.0. M-9 medium had the following composition: $\mathrm{Na}_{2} \mathrm{HPO}_{4} \cdot 12 \mathrm{H}_{2} \mathrm{O}, 12 \mathrm{~g} ; \mathrm{KH}_{2} \mathrm{PO}_{4}$, $3 \mathrm{~g} ; \mathrm{NaCl}, 500 \mathrm{mg} ; \mathrm{NH}_{4} \mathrm{Cl}, 1 \mathrm{~g} ; \mathrm{MgSO}_{4} \cdot 7 \mathrm{H}_{2} \mathrm{O}, 246 \mathrm{mg}$; $\mathrm{CaCl}_{2}, 11 \mathrm{mg}$; $\mathrm{L}$-arabinose or D-xylose, $4 \mathrm{~g}$; and distilled water, $1000 \mathrm{ml}, \mathrm{pH} 7.0$.

Growth condition. E. coli IFO 3545 and L-arabinosenegative mutants of the strain were subcultured in $3 \% \mathrm{NB}$ $(\mathrm{pH} 7.0)$ overnight at $30^{\circ} \mathrm{C}$ without aeration. Unless otherwise stated, they were grown at $30^{\circ} \mathrm{C}$ and $\mathrm{pH} 7.0$ with vigorous aeration on a shaker by the previously described method.9) The bacterial growth was also measured as previously described. ${ }^{9)}$

Measurement of bulge cells. As previously indicated,9' typical morphological changes induced by L-arabinose under hypertonic condition with $5 \%$ sodium chloride were as follows: 1) bulge formation (site-specific swelling or expansion observed usually at the middle of rod cells reminiscent of penicillin-induced bulges ${ }^{10)}$ ); 2) transformation of rod cells to spheres. Spherical cells seemed to appear via the process of 1) but were distinguished from bulge cells in that spherical cells completely lost the original rod shape. The bacterial cells showing the above morphological changes were prevented from dramatic lysis when kept in the above hypertonic medium. Thus, more than 200 cells were observed per sample under an Olympus FHT microscope with a Bacterial Counting Chamber (Erma Tokyo) without staining and the bacterial cells showing the above morphological changes were all counted as bulge cells.

Isolation of $\mathrm{L}$-arabinose-negative mutants. An overnight culture of $E$. coli IFO 3545 with $3 \% \mathrm{NB}$ at $30^{\circ} \mathrm{C}$ was inoculated into $5 \mathrm{ml}$ of the same medium, and was grown for $3 \mathrm{hr}$ at $30^{\circ} \mathrm{C}$. The cells were harvested by centrifugation and suspended in $50 \mathrm{~mm}$ Tris-maleate buffer, $\mathrm{pH} \mathrm{6.0,} \mathrm{after}$ they were washed twice with the same buffer. The suspension was irradiated with $\mathrm{UV}$ until a survival of 0.1 to $1.0 \%$ was obtained. Washed cells were also mutagenized with $N$ methyl- $N^{\prime}$-nitro- $N^{\prime}$-nitrosoguanidine $(1.2 \mathrm{mg}$ per $10 \mathrm{ml}$ of the cell suspension). Surviving cells were then streaked onto EMB-agar plates and grown at $30^{\circ} \mathrm{C}$. Isolates showing white to pinkish color on the plate were replicated to both M-9 (L-arabinose) medium and M-9 (D-xylose) medium and grown for 2 or 3 days at $30^{\circ} \mathrm{C}$. Each strain which could produce colonies with $\mathrm{D}$-xylose but not with Larabinose was purified. Consequently, ara-207, ara-208, ara-209, ara-211, and ara-214 were selected as $\mathrm{L}-$ arabinose-negative mutants deficient in either $\mathrm{L}$-arabinose permease, L-arabinose isomerase, L-ribulokinase, Lribulose-5-phosphate (L-Ru5P) 4-epimerase, or the operator of the L-arabinose operon.

Enzyme assay. L-Arabinose isomerase: L-Arabinose isomerase was assayed using a toluene-treated cell suspension as described below. Wild type and several Larabinose-negative mutants were grown in $3 \% \mathrm{NB}$ containing $1 \% \mathrm{~L}$-arabinose for 4 or $5 \mathrm{hr}$ at $30^{\circ} \mathrm{C}$ with vigorous aeration. The cells were harvested by centrifugation and washed twice with $0.1 \mathrm{M}$ Tris- $\mathrm{HCl}$ buffer, $\mathrm{pH} 7.5$, containing $0.005 \%$ chloramphenicol and $10 \mathrm{mM} \mathrm{MnCl}_{2} \cdot 4 \mathrm{H}_{2} \mathrm{O}$. The washed cell suspension $(5 \mathrm{ml})$ was vigorously shaken with $50 \mu$ l of toluene after the optical density of the cell suspension at $660 \mathrm{~nm}$ was adjusted to 0.8 , to make the cells permeable. Then, the permeable cell suspension $(1 \mathrm{ml})$ was incubated with $0.08 \mathrm{ml}$ of $20 \%$ L-arabinose for 15 to $60 \mathrm{~min}$ at $37^{\circ} \mathrm{C}$. L-Ribulose produced in the reaction was determined by the cystein-carbazole method. ${ }^{12)}$ One unit was defined as the amount of enzyme that produced $1 \mu \mathrm{mol}$ of L-ribulose per min under the conditions described above.

L-Ribulokinase. L-Ribulokinase was assayed using a cellfree extract of each strain by a modification of the method of Burma and Horecker. ${ }^{13)}$ Washed cells obtained as above were sonicated using a $10 \mathrm{kc}$ Branson Sonifier B-12 three times for $3 \mathrm{~min}$. The supernatant obtained after centrifugation at $10,000 \times g$ for $30 \mathrm{~min}$ and dialysis against $0.1 \mathrm{~m}$ Tris- $\mathrm{HCl}$ buffer, $\mathrm{pH} 7.5$ was used as an enzyme solution. A reaction mixture containing $7 \mu \mathrm{mol}$ of $\mathrm{L}$ ribulose, $30 \mu \mathrm{mol}$ of $\mathrm{MgCl}_{2} \cdot 6 \mathrm{H}_{2} \mathrm{O}, 15 \mu \mathrm{mol}$ of ATP, and the enzyme in $2.0 \mathrm{ml}$ of the above buffer was incubated for $30 \mathrm{~min}$ at $37^{\circ} \mathrm{C}$. A control reaction was run without the addition of L-ribulose. Each supernatant $(100 \mu \mathrm{l})$ obtained after boiling the reaction mixture and removing denatured protein by centrifugation was mixed with $2.9 \mathrm{ml}$ of the above buffer containing $3 \mu \mathrm{mol}$ of phosphoenolpyruvate, $300 \mu \mathrm{mol}$ of $\mathrm{KCl}, 30 \mu \mathrm{mol}$ of $\mathrm{MgCl}_{2} \cdot 6 \mathrm{H}_{2} \mathrm{O}, 1 \mu \mathrm{mol}$ of NADH, 30 units of lactate dehydrogenase, 30 units of pyruvate kinase. Decrease in the absorbance at $340 \mathrm{~nm}$ was measured in a Shimadzu UV-200 spectrophotometer using cells of $1-\mathrm{cm}$ light pass length and converted to the amount of ADP produced by the action of L-ribulokinase. One unit was defined as the amount of enzyme which produced $1 \mu \mathrm{mol}$ of ADP per min under the conditions described above.

L-Ribulose-5-phosphate (L-RuSP) 4-epimerase. The above cell-free extract was also used for the assay of $\mathrm{L}$ Ru5P 4-epimerase by the method of Lee et al. ${ }^{14)}$ with a little modification. A mixture contained glycylglycine $(\mathrm{pH}$ 8.5), $30 \mu \mathrm{mol}$; thiamine pyrophosphate, $1.2 \mu \mathrm{mol}$; $\mathrm{MgCl}_{2} \cdot 6 \mathrm{H}_{2} \mathrm{O}, 12 \mu \mathrm{mol} ; \quad \mathrm{NADH}, \quad 0.7 \mu \mathrm{mol} ; \quad$ L-Ru5P, $10 \mu \mathrm{mol}$; transketolase, 1 unit; $\alpha$-glycerophosphate dehydrogenase-triosephosphate isomerase, 1 unit, in a total volume of $2.56 \mathrm{ml}$. The rection was started by the 
addition of enzyme $(100 \mu 1)$ to the mixture and was followed by a decrease in absorbance at $340 \mathrm{~nm}$ to give a corresponding amount of $\mathrm{D}-\mathrm{Xu} 5 \mathrm{P}$ formed as a result of the 4-epimerase reaction. A control reaction was run without the addition of L-Ru5P. One unit was defined as the amount of enzyme which produced $1 \mu \mathrm{mol}$ of $\mathrm{D}-\mathrm{Xu} 5 \mathrm{P}$ under these conditions.

Quantitative analysis of sugars and protein. L-Arabinose was determined by the $o$-aminodiphenyl-acetic acid method. ${ }^{15)}$ L-Ribulose was determined by the cysteincarbazole test ${ }^{12)}$ using commercially obtained D-ribulose as a standard. Protein was measured by the method of Lowry et al. ${ }^{16)}$ using bovine serum albumin as a standard.

Chemicals. L-Arabinose was purchased from Wako Pure Chemical Industries, Ltd. L-Ribulose was prepared from Larabinose by the method of Glatthaar and Reichstein. ${ }^{17)} \mathrm{L}$ Arabinose could not be detected in the L-ribulose preparation obtained above. L-Ru5P was prepared from Lribulose by a phosphorylation reaction of L-ribulokinase by the method of Simpson and Wood. ${ }^{18)}$ The purity of LRu5P preparation thus obtained was analyzed as its trimethylsilyl derivative by gas-liquid chromatography as reported previously ${ }^{19)}$ where it gave a singe peak with the same retention time as D-ribulose-5-phosphate commercially obtained. A colorimetric method could not detect contamination by L-ribulose at a significant level. The Lribulokinase used in the above reaction was a preparation partially purified from are-207, which was grown in 11 of $3 \% \mathrm{NB}$ containing $1 \%$ L-arabinose for $4.5 \mathrm{hr}$ at $30^{\circ} \mathrm{C}$, by salting out with $\left(\mathrm{NH}_{4}\right)_{2} \mathrm{SO}_{4}(40 \sim 50 \%$ saturation $)$ by the method of Lee and Bendert. ${ }^{20)} \mathrm{D}$-Ribulose and D-ribulose5-phosphate were purchased from Sigma Chemical Co. ATP, phosphoenolpyruvate, and NADH were from Oriental, Yeast Co., Ltd. Pyruvate kinase (rabbit muscle) and lactate dehydrogenase (rabbit muscle) were also from Oriental Yeast Co., Ltd. Transketolase (Type X from bakers yeast) and $\alpha$-glycerophosphate dehydrogenasetriosephosphate isomerase (Type III from rabbit muscle) were products of Sigma Chemical Co. Other chemicals and reagents were of analytical grade.

\section{RESULTS}

\section{Mutational sites of $\mathrm{L}$-arabinose-negative $m u$ - tants}

The following L-arabinose non-utilizing mutants from IFO 3545 strain were used in the present study: ara-207; ara-208; ara-209; ara211; ara-214. They could grow in both $1 \% \mathrm{NB}$ and $3 \% \mathrm{NB}$ with almost the same growth rate as the wild type. According to phenotype, they were found to have mutational sites either in $\mathrm{L}$ arabinose isomerase, L-ribulokinase, L-Ru5P 4-epimerase, L-arabinose permease or the operator of the $\mathrm{L}$-arabinose operon involved in the initial L-arabinose metabolism. The mutational sites of these mutant strains were finally decided as shown in Table I on the basis of each L-arabinose metabolizing enzyme activity and the manner of L-ribulose accumulation.

\section{Bulge formation of each mutant strain under hypertonic condition with $5 \%$ sodium chloride We found that bulge cells appeared with high frequency even in the early stages of}

Table I. Characterization of L-Arabinose-negative Mutant Strains of E. coli IfO 3545

\begin{tabular}{|c|c|c|c|c|c|}
\hline \multirow[b]{2}{*}{ Strain } & \multicolumn{3}{|c|}{ Activity } & \multirow{2}{*}{$\begin{array}{l}\text { Accumulation } \\
\text { of L-ribulose } \\
(\mu \mathrm{mol} / \mathrm{ml})\end{array}$} & \multirow{2}{*}{ Block } \\
\hline & $\begin{array}{l}\text { L-Arabinose } \\
\text { isomerase } \\
\text { (units/mg } \\
\text { dry cell) }\end{array}$ & $\begin{array}{l}\text { L-Ribulokinase } \\
\text { (units/mg } \\
\text { protein) }\end{array}$ & $\begin{array}{c}\text { L-Ru5P } \\
\text { 4-epimerase } \\
\text { (units/mg } \\
\text { protein) }\end{array}$ & & \\
\hline Wild type & 0.106 & 0.034 & 0.076 & 0.05 & \\
\hline Ara-207 & 0.064 & 0.014 & 0.000 & 0.73 & 4-Epimerase ${ }^{b}$ \\
\hline Ara-208 & 0.071 & 0.016 & 0.000 & 0.93 & 4-Epimerase \\
\hline Ara-209 & 0.248 & 0.000 & 0.032 & 9.61 & L-Ribulokinase \\
\hline Ara-211 & 0.316 & 0.000 & 0.060 & 6.48 & L-Ribulokinase \\
\hline Ara-214 & 0.000 & 0.056 & 0.117 & 0.06 & Isomerase ${ }^{c}$ \\
\hline
\end{tabular}

a The amount of L-ribulose was measured for the supernatant obtained from 24 -hr culture of each strain with $3 \%$ NB containing $1 \%$ L-arabinose at $30^{\circ} \mathrm{C}$.

${ }^{b} \quad$ L-Ribulose-5-phosphate 4-epimerase.

c L-Arabinose isomerase. 
Table II. Bulge Formation of E. coli IFO 3545

WiLd TYPE AND L-ARABINOSE-NEGATIVE MUTANTS UNDER HYPERTONIC CONDITION WITH $5 \% \mathrm{NaCl}^{a}$

\begin{tabular}{|c|c|c|c|}
\hline \multirow{2}{*}{ Strain } & \multicolumn{2}{|c|}{ No. of cells $/ \mathrm{ml}$} & \multirow{2}{*}{$\begin{array}{c}\text { Ratio of } \\
\text { bulge cells } \\
(\%)\end{array}$} \\
\hline & Total cell & Bulge cell & \\
\hline Wild type & $3.15 \times 10^{7}$ & $2.38 \times 10^{7}$ & 75.6 \\
\hline Ara-207 & $3.70 \times 10^{7}$ & $2.99 \times 10^{7}$ & 80.8 \\
\hline Ara-208 & $3.21 \times 10^{7}$ & $2.45 \times 10^{7}$ & 76.3 \\
\hline Ara-209 & $3.89 \times 10^{7}$ & 0 & 0 \\
\hline Ara-211 & $4.35 \times 10^{7}$ & 0 & 0 \\
\hline Ara-214 & $1.63 \times 10^{7}$ & 0 & 0 \\
\hline
\end{tabular}

a Each strain was grown in $2 \mathrm{ml}$ of $1 \% \mathrm{NB}(\mathrm{pH} \mathrm{5.0)}$ containing $1 \% \mathrm{~L}$-arabinose and $5 \% \mathrm{NaCl}$ for $24 \mathrm{hr}$ at $30^{\circ} \mathrm{C}$.

cultivation when the bacterial cells had been subcultured using $1 \% \mathrm{NB}$ containing $5 \%$ sodium chloride and inoculated into the medium with acidic $\mathrm{pH}$. Thus, L-arabinose-induced bulge cell formation was examined at $\mathrm{pH} 5.0$ for the wild type and L-arabinose-negative mutants obtained above having no or different mutational sites in the initial $\mathrm{L}$-arabinose metabolism. As shown in Table II, bulge cell formation was observed in the wild type as well as ara-207 and ara-208 deficient in LRu5P 4-epimerase with the same frequency. However, such a morphological change was not observed in the other mutants deficient in L-arabinose isomerase and L-ribulokinase. This indicated that $\mathrm{L}$-arabinose must be metabolized to L-Ru5P via the sequential reaction of these enzymes to induce bulge cell appearance.

\section{Bulge formation without sodium chloride}

The above result also suggested that the presence of $5 \%$ sodium chloride affected the level or in vivo activity of L-Ru5P 4-epimerase to cause accumulation of L-Ru5P in the wild type, because bulge cells were formed only in ara-207 and ara-208 which could not metabolize this compound due to a genetic defect of 4 epimerase. Bulge formation was likely to occur in L-Ru5P 4-epimerase deficient mutants under conditions without sodium chloride. Thus, the

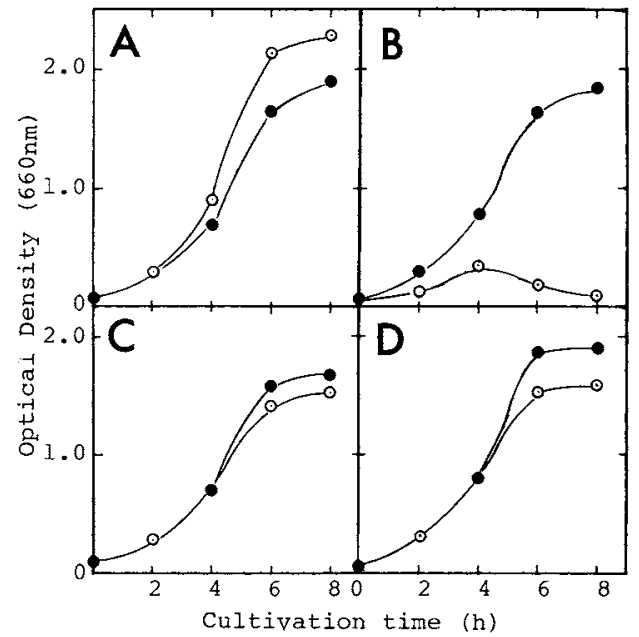

FIG. 1. Effects of L-Arabinose on the Growth of E. coli IFO 3545 Wild Type and L-Arabinose-negative Mutants with $1 \% \mathrm{NB}$.

Each strain was grown in $5 \mathrm{ml}$ of $1 \% \mathrm{NB}(\boldsymbol{O})$ or $1 \% \mathrm{NB}$ containing $1 \% \mathrm{~L}$-arabinose $(\mathrm{O})$ at $30^{\circ} \mathrm{C}$. A, wild type; B, ara-207; C, ara-211; D, ara-214

effects of L-arabinose on growth and morphological change were examined for the wild type, ara-207, ara-211, and ara-214 using 1\% $\mathrm{NB}$ in the absence of sodium chloride.

The presence of L-arabinose inhibited the growth of ara-211 and ara-214 a little, though the growth of the wild type was promoted to a certain extent, as shown in Fig. 1. The growth of ara-207 was strongly inhibited by Larabinose from the beginning of cultivation, resulting in immediate lysis at $4 \mathrm{hr}$ without any osmotic shock. Morphological changes were followed under a microscope, showing that the growth of ara-207 was first accompanied by cell elongation until $2 \mathrm{hr}$ of cultivation (Fig. 2). Dramatic changes in morphology such as swelling of the typical rod shape and bulge formation were found to have occurred by $4 \mathrm{hr}$ of cultivation. At $6 \mathrm{hr}$, spherical cells were dominant instead of bulged cells, and the total cell number was found to have decreased significantly under a microscope. L-Arabinose could cause exactly the same pattern of morphological change in ara-208 as described above.

Changes in the numbers of normal cells 


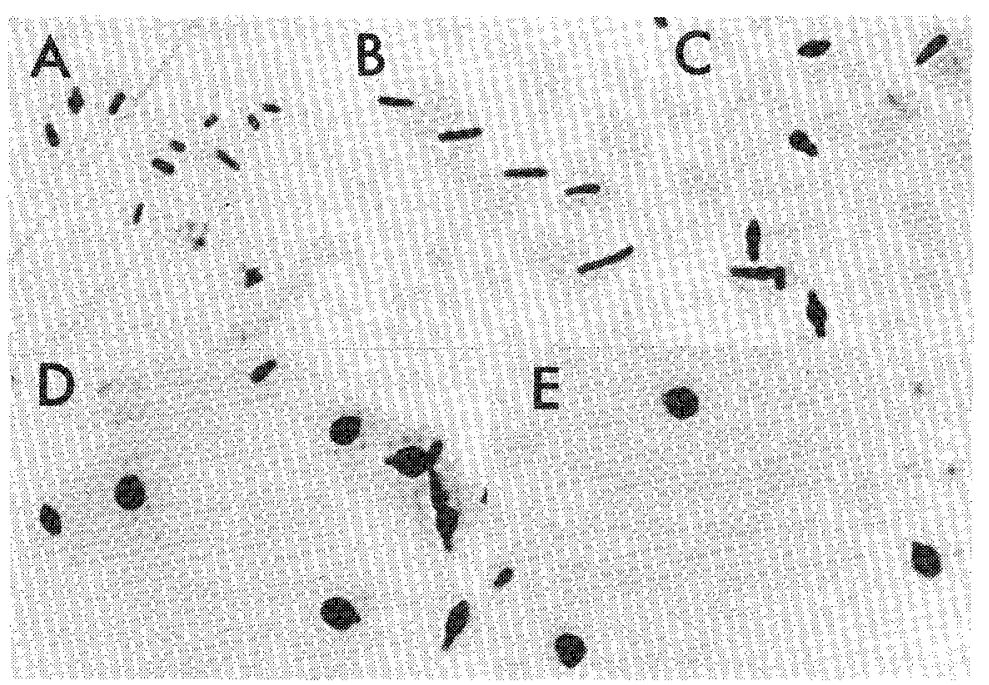

FIG. 2. Photomicrographs Showing Morphological Change of Ara-207 during Growth in $5 \mathrm{ml}$ of $1 \%$ NB Containing 1\% L-Arabinose at $0 \mathrm{hr}(\mathrm{A}), 2 \mathrm{hr}(\mathrm{B}), 4 \mathrm{hr}(\mathrm{C}), 6 \mathrm{hr}(\mathrm{D})$ and $8 \mathrm{hr}(\mathrm{E})$.

(osmotically stable cells) were also examined during the cultivation with $1 \% \mathrm{~L}$-arabinose. As shown in Fig. 3, the number of osmotically stable cells decreased from the beginning of cultivation with $\mathrm{L}$-arabinose, giving rise to a $1 \%$ survival of the original level at $7.5 \mathrm{hr}$. The increase in the turbidity of ara-207 observed until $4 \mathrm{hr}$ of cultivation with L-arabinose (Fig. 1) did not depend on cell division of normal rod cells but on cell elongation and swelling as a step of bulge and spherical cell formation with much osmotic fragility.

\section{Bulge formation in resting cells}

$\beta$-Lactam antibiotics such as penicillin kill growing cells of $E$. coli but not resting cells. In this study, the effects of $\mathbf{L}$-arabinose on growth and morphological change were examined for the resting cells of ara-207. Washed cell suspension of ara-207 was prepared from an overnight culture $(20 \mathrm{ml})$ with $3 \% \mathrm{NB}$ by repeated washing with $0.02 \mathrm{M}$ phosphate buffer,

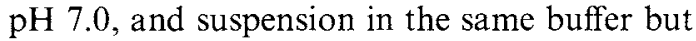
containing $1 \% \mathrm{~L}$-arabinose to give an optical density of 0.2 at $660 \mathrm{~nm}$. When the above cell suspension was incubated with shaking at $37^{\circ} \mathrm{C}$, no change in the bacterial cell shape could be observed. On the other hand, lysis of ara- 207 could be prevented by the addition of

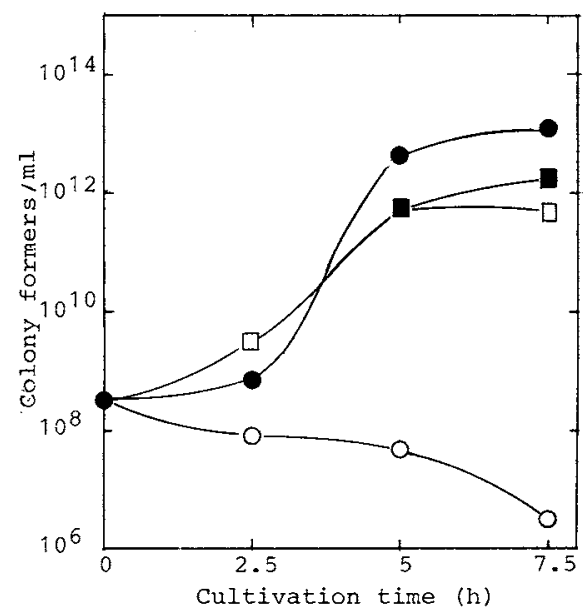

FIG. 3. Change in the Number of Osmotically Stable Cells of $E$. coli IFO 3545 Wild Type and L-Arabinosenegative Mutants during Growth in $5 \mathrm{ml}$ of $1 \% \mathrm{NB}$ Containing $1 \%$ L-Arabinose.

Each strain was plated on $3 \%$ NB-agar plate after osmotic shock by dilution with distilled water. Colony formers were counted as osmotically stable cells. Wild type, ara-207, O; ara-211, $\mathbf{\square}$; ara-214, $\square$.

chloramphenicol into an exponentially growing culture at $2 \mathrm{hr}$ and $3 \mathrm{hr}$, as shown in Fig. 4. Bulged cells and spherical cells were not seen during the following cultivation with chloramphenicol. However, the addition of chloramphenicol at $4 \mathrm{hr}$ failed to prevent the following 


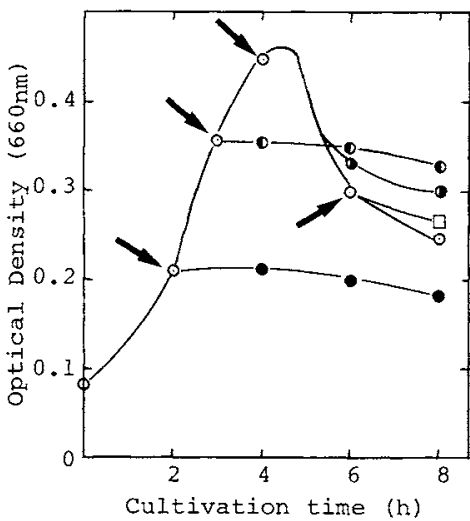

FIG. 4. Effects of Chloramphenicol on L-Arabinoseinduced Bacteriolysis of Ara-207.

Ara-207 was grown in 5 test tubes containing $5 \mathrm{ml}$ of $1 \%$ NB supplemented with $1 \%$ L-arabinose at $30^{\circ} \mathrm{C}$. Chloramphenicol was not added (O) or added to the growing cultures of ara-207 at $2 \mathrm{hr}(\mathbf{O}), 3 \mathrm{hr}(\mathrm{O}), 4 \mathrm{hr}(\mathbf{O})$, and $6 \mathrm{hr}(\square)$, respectively, at the concentration of $25 \mu \mathrm{g}$ per $\mathrm{ml}$. Arrows indicate the time when chloramphenicol was added.

dramatic lysis, indicating that cells of ara-207 had become fragile enough at that time.

\section{DISCUSSION}

L-Ru5P 4-epimerase deficient mutants of $E$. coli were first isolated by Engresberg $e t$ al. as Larabinose-negative, L-arabinose-sensitive mutants of $E$. coli $\mathrm{B} / \mathrm{r}$, representing the presence of another gene locus (gene D) in the Larabinose operon. ${ }^{21)}$ Addition of L-arabinose to the growing culture clearly inhibited the growth of these mutant strains, resulting in typical bacteriostasis ${ }^{21)}$, while D-galactosenegative mutants of $E$. coli $\mathrm{K}-12$ were reported to show differential sensitivity to D-galactose, bacteriostasis and-lysis according to the lack of D-galactose-1-phosphate uridyltransferase and UDPgalactose 4-epimerase, respectively. ${ }^{22)}$ Spheroplast formation of a Salmonella sp. by D-galactose was a morphological change first observed as an effect of a monosaccharide on a bacterial mutant deficient in the enzyme metabolizing it such as UDPgalactose 4-epimerase. ${ }^{23)}$ This suggests that accumulation of UDPgalactose within the cell may be responsible for inhibition of the bacterial cell wall synthesis.

In this study, L-arabinose-induced bulge formation was demonstrated only in ara-207 and ara-208, deficient in L-Ru5P 4-epimerase, as well as the wild type when they were grown under hypertonic conditions with $5 \%$ sodium chloride. This should lead us to the conclusion that bulge formation can not be induced when $\mathrm{L}$-arabinose is not metabolized to $\mathrm{L}-\mathrm{Ru} 5 \mathrm{P}$ and the intracellular level or in vivo activity of $\mathrm{L}$ Ru5P 4-epimerase is closely related to such a dramatic morphological change in the bacterium. The presence of sodium chloride should regulate the above enzyme level or activity so that one of $\mathrm{L}$-arabinose metabolites, L-Ru5P, accumulates within the cell. In fact, $8.2 \mathrm{mg}$ of L-Ru5P could be detected in the extract of wild type cells obtained from $1 \% \mathrm{NB}$ $(100 \mathrm{ml})$ supplemented with $1 \%$ L-arabinose and $5 \%$ sodium chloride at $48 \mathrm{hr}$ but the amount of L-Ru5P was negligible when the cells were from the medium without sodium chloride (Tanaka, Sunada, Muroi, Taniguchi and $\mathrm{Oi}$, unpublished results).

$\beta$-Lactam antibiotics cause severe lysis when added to a growing culture of $E$. coli at high concentrations. They show differential effects on the morphology of the bacterium at lower concentrations according to their affinity for each of the penicillin binding proteins. ${ }^{1)}$ When peptidoglycan synthesis is inhibited by low penicillin $G$ or ampicillin, a hydrolase is thought to weaken the layer, resulting in expansion of the bacterial cell at the site of cell division (septum formation), the bulge. ${ }^{10}$ Thus, we thought that bulge formation induced with L-arabinose may represent a specific inhibition of peptidoglycan metabolism similar to those with several penicillins described above. First, the appearance of bulge cells paralleled the inhibition of the bacterial growth and transformation of normal rod cells to osmotically fragile cells in $1 \% \mathrm{NB}$ containing $1 \%$ L-arabinose (see Figs. 1 and 2). Next, morphological change and the following lysis were observed in the growing culture but not in the resting cells. 
It is still unclear if L-Ru5P, once accumulated in the $E$. coli cell, can directly induce bulge cells by inhibiting the peptidoglycan metabolism. As described above, some sugar phosphate esters or their derivatives are likely to have such a biological function. The presence of $4 \%$ sodium chloride (the lowest concentration effective for bulge formation in $E$. coli IFO $3545^{9}$ ) still severely inhibited the growth of $E$. coli $\mathrm{K}-12$ G6MD3, ${ }^{24)}$ in which cell elongation and swelling observed along with bulge formation of IFO 3545 strain were not observed (Tanaka, unpublished result). L-Arabinose-induced morphological change seems to be a characteristic observed in $E$. coli strain such as IFO 3545 having higher salt resistance. Although the presence of $5 \%$ sodium chloride was not critical for cellular functions of IFO 3545 to increase cellular mass, ${ }^{9)}$ it should have an apparent effect on intracellular levels or the activity of L-Ru5P 4-epimerase. Henneman and Umbreit reported that the in vivo activity of glucose-6-phosphate dehydrogenase is osmotically inhibited in $E$. coli $\mathrm{B}$ by the presence of $0.2 \sim 0.5 \mathrm{M}$ sodium chloride, resulting in repression of the bacterial respiration rate. ${ }^{8)}$ In $E$. coli, the genes of $\mathrm{L}$-arabinose metabolizing enzymes form a cluster, the L-arabinose operon, with a common regulatory site. ${ }^{21)}$ Thus, it seems impossible to separately regulate the expression of each structural gene. Intracellular accumulation of L-Ru5P itself reflects the contribution of $\mathrm{L}$-arabinose isomerase and L-ribulokinase for production of this compound, suggesting the presence of L-Ru5P 4epimerase at an appreciable level. The presence of sodium chloride may affect the in vivo activity of this enzyme as is the case with glucose-6-phosphate dehydrogenase. Further investigations are necessary to solve these questions.

\section{REFERENCES}

1) P. O. Scheie, J. Bacteriol., 98, 335 (1969).

2) P. O. Scheie and R. Rehberg, J. Bacteriol., 109, 229 (1972).

3) G. Dhavises and G. D. Anagnostopoulos, Microbios Lett., 7, 105 (1979).

4) G. Dhavises and G. D. Anagnostopoulos, Microbios Lett., 7, 149 (1979).

5) W. V. Alphen and B. Lugtenberg, J. Bacteriol., 131, 623 (1977).

6) G. F. Munro, K. Hercules, J. Morgen and W. Sauerbauer, J. Biol. Chem., 247, 1272 (1972).

7) S. D. Roller and G. D. Anagnostopoulos, J. AppI. Microbiol., 52, 425 (1982).

8) D. H. Henneman and W. W. Umbreit, J. Bacteriol., 87, 1274 (1964).

9) T. Tanaka, G. Dhavises, M. Taniguchi and S. Oi, Agric. Biol. Chem., 50, 2663 (1986).

10) U. Schwarz, A. Asmus and H. Frank, J. Mol. Biol., 41, 419 (1969).

11) B. G. Spratt, Proc. Natl. Acad. Sci. U.S.A., 72, 2999 (1975).

12) Z. Dische and E. Borenfreund, J. Biol. Chem., 192, 583 (1951).

13) D. P. Burma and B. L. Horecker, J. Biol. Chem., 231, 1039 (1958).

14) N. Lee, J. W. Patrick and M. Masson, J. Biol. Chem., 243, 4700 (1968).

15) T. E. Timell, C. P. J. Glaudemans and A. L. Currie, Anal. Chem., 28, 1916 (1956).

16) O. H. Lowry, N. J. Rosebrough, A. L. Farr and R. J. Randall, J. Biol. Chem., 193, 265 (1951).

17) C. Glatthaar and T. Reichstein, Helv. Chim. Acta, 18, 80 (1935).

18) F. J. Simpson and W. A. Wood, J. Biol. Chem., 230, 472 (1958).

19) T. Tanaka and S. Oi, Agric. Biol. Chem., 49, 939 (1985).

20) N. Lee and I. Bendert, J. Biol. Chem., 242, 2043 (1967).

21) E. Englesberg, R. L. Anderson, R. Weinberg, N. Lee, P. Hoffee, G. Huttenhauer and H. Boyer, $J$. Bacteriol., 84, 137 (1962).

22) M. B. Yarmolinsky, H. Wiesmeyer, H. M. Kalckar and E. Jordan, Proc. Natl. Acad. Sci. U.S.A., 45, 1786 (1959).

23) T. Fukasawa and H. Nikaido, Biochim. Biophys. Acta, 48, 470 (1961).

24) M. Schwarz, J. Bacteriol., 92, 1083 (1966). 